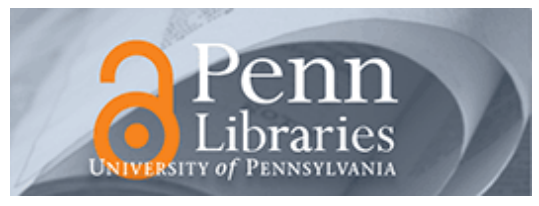

University of Pennsylvania

ScholarlyCommons

Accounting Papers

Wharton Faculty Research

$5-2011$

\title{
Discussion of The Value of Financial Statement Verification in Debt Financing: Evidence from Private U.S. Firms
}

Gavin Cassar

University of Pennsylvania

Follow this and additional works at: https://repository.upenn.edu/accounting_papers

Part of the Accounting Commons

\section{Recommended Citation}

Cassar, G. (2011). Discussion of The Value of Financial Statement Verification in Debt Financing: Evidence from Private U.S. Firms. Journal of Accounting Research, 49 (2), 507-528. http://dx.doi.org/10.1111/ j.1475-679X.2011.00412.x

This paper is posted at ScholarlyCommons. https://repository.upenn.edu/accounting_papers/70

For more information, please contact repository@pobox.upenn.edu. 


\title{
Discussion of The Value of Financial Statement Verification in Debt Financing: Evidence from Private U.S. Firms
}

\begin{abstract}
I discuss Minnis [2010] in the context of the broader literature on private firm financing. In particular, I focus on the unique features of the private firm setting and how it affects research design and inference. I detail the alternative information sources available to debt financiers of private firms that may limit the role of auditors and firm financial statements. I review research in the private firm setting that documents the heightened importance of many omitted correlated variables such as the loan characteristics, contractual terms, and the characteristics of the entrepreneur that affect cost of debt. In evaluating the validity of Minnis's [2010] hypotheses and econometric methods, I report findings from a representative sample of private firms provided by the Federal Reserve Board's Survey of Small Business Finances.
\end{abstract}

\section{Keywords}

auditing, cost of capital, earnings persistence, private firms

Disciplines

Accounting 


\title{
Discussion of The Value of Financial Statement Verification in Debt Financing: Evidence from Private U.S. Firms
}

\author{
Gavin Cassar
}

The Wharton School

University of Pennsylvania

January 2011

\begin{abstract}
:
I discuss Minnis [2010] in the context of the broader literature on private firm financing. In particular, I focus on the unique features of the private firm setting and how it affects research design and inference. I detail the alternative information sources available to debt financiers of private firms that may limit the role of auditors and firm financial statements. I review research in the private firm setting that documents the heightened importance of many omitted correlated variables such as the loan characteristics, contractual terms, and the characteristics of the entrepreneur that affect cost of debt. In evaluating the validity of Minnis's [2010] hypotheses and econometric methods, I report findings from a representative sample of private firms provided by the Federal Reserve Board's Survey of Small Business Finances.
\end{abstract}

JEL Classification Codes: D82; G20; L14; M42.

Keywords: auditing; cost of capital; earnings persistence; private firms.

Data Availability: The data used in this study are publicly available from the Federal Reserve Board.

* Contact details: The Wharton School, University of Pennsylvania, Steinberg Hall-Dietrich Hall (Suite 1300), 3620 Locust Walk, Philadelphia, PA 19104-6365. cassar@wharton.upenn.edu (215) 898 2023. This discussion is based on the working paper version December 2010 and one round of editorial comments. I appreciate the detailed comments from Philip Berger and helpful discussions with Richard Lambert and Teri Yohn. 


\section{Discussion of The Value of Financial Statement Verification in Debt Financing: Evidence from Private U.S. Firms}

\section{Introduction}

Minnis [2010] explores the hypothesis that audited financial statements are more informative than unaudited financial statements in private firms. Specifically, he argues that audit verification of firms’ accounting process and reporting gives financial statements greater credibility, resulting in a lower cost of debt for audited firms. Using an endogenous switching model to control for the voluntary choice of using an auditor, he finds audited firms have an interest rate 69 basis points lower than non-audited firms. Further, he observes audited firms’ cost of debt is more sensitive to variations in some financial statement variables than non-audited firms.

There is a substantial literature in finance and accounting on cost of debt in private firms, in part attributable to the large representative samples from the Federal Reserve Board administered Survey of Small Business Finances (SSBF). Specifically, Minnis [2010] provides further evidence of the role of auditing on private firms' cost of debt. Survey and experimental research finds that users, such as bank loan officers, generally regard audited financial statements to be more credible and reliable than non-audited financial statements (Reckers and Pany 1979; McKinley, Pany, and Reckers

1985; Pillsbury 1985; Nair and Rittenberg 1987; Strawser 1991). However, these studies also generally fail to find an association between auditor use or quality and firms’ cost of debt (Houghton 1983; McKinley, Puny, and Reckers 1985; Johnson, Pany, and White 1983; Pany and Smith 1982). Archival studies on private firms' cost of debt and auditor engagement have also provided mixed evidence. Blackwell, Noland, and Winters [1998] find auditor use associated with lower interest rates in 212 revolving credit agreements from six US banks. Allee and Yohn [2010], using a representative sample of 1,481 US private firms, finds no association between audit association and cost of debt. Kim, Simunic, Stein and Yi [2007], using a panel sample of 9,168 privately held Korean firm-years 
find lower interest rate spreads for audited firms and even lower spreads for firms with Big 4 auditors. Further, exploiting the panel nature of their data they find firms that change from being not audited to audited have significant reductions in their cost of debt. Minnis provides evidence consistent with auditing reducing firms' cost of debt after controlling for firms' endogenous audit choice.

In more novel evidence, Minnis provides a mechanism for why firms with audited financial statements have lower cost of debt. He argues that audit verification improves the predictive ability of reported net income on future cash flows. Regressing one-year ahead cash flows from operations on contemporaneous net income, he finds net income better predicts future cash flows in audited financial statements compared to non-audited financial statements. Decomposing net income into its cash flow and accrual components, he observes that both cash flow and accruals have greater persistence for audited firms than non-audited firms. These findings are consistent with recent evidence that suggests auditors do affect financial reporting properties in private firms (CanoRodriguez 2010). Finally, partitioning the sample by firm size, he finds both the interest rate reduction and the improvement of net income predictive ability from auditing is concentrated in smaller firms. He argues that auditors have incrementally more expertise to enhance smaller firms' accrual estimation process as smaller firms have weaker internal accounting capabilities than larger firms. Overall, Minnis investigates an important and timely topic as accounting regulators are placing increasing emphasis on accounting methods in privately-held businesses, particularly the costs and benefits of mandating GAAP and other accounting practices on smaller firms (AICPA/FASB 2006; IASB 2007).

In section 2, I describe the unique features of the private firm setting and how it affects research design and inference. First, I discuss the effect of sample selection choices on the study findings. Second, I detail the alternative information sources available to debt financiers of private 
firms that may be more important than, or diminish the role of, audited financial statements. Third, I review research in the private firm setting that documents important firm-lender information asymmetries and the many omitted correlated variables such as the loan characteristics, contractual terms, and the characteristics of the entrepreneur that affect cost of debt and likely affect Minnis's findings. Fourth, I use Minnis's cost of debt measure as an example to discuss how some measurement concerns are exacerbated in smaller private firms.

In Section 3, I discuss more specifically the validity of the econometric methods employed and the specific hypotheses. First, I provide examples where auditing is not voluntary for private firms. Second, I provide several concerns of conference participants that raise doubts as to the validity of the instrument used in the paper and I conjecture about what it may be capturing. Third, I discuss propensity matching and the importance of firm size on the observed findings. In Section 4, I raise questions about the validity of Minnis's findings and the arguments underlying his second and third hypotheses. I also question whether the size-based results are driven by firms' internal capabilities or one of the many other size-correlated constructs. Section 5 concludes.

\section{Private Firm Setting}

The strength of the private firm setting is the exposure to varied environmental, regulatory, and other forces compared to those that affect public firms, providing an important laboratory to investigate fundamental accounting issues. Private firms provide a more powerful setting to examine the use of auditors on cost of debt capital than publicly-listed firms given the greater information asymmetries and risk of default. There is a strong nexus between financial reporting and cost of debt as lenders are the primary external users of financial reports from small, privately-held firms (Nair and Rittenberg, 1983). Further, like other mandated accounting practices for public firms, many private businesses have no regulatory requirements for being audited. While the economic magnitudes are not generalizable to public firms, the strength of the hypothesized influence of 
accounting verification, and the empirical variation in the accounting and dependent variables make private firms an ideal sample to investigate this fundamental accounting issue.

\subsection{SAMPLE REPRESENTATIVENESS}

The sample used by Minnis [2010] is a reasonably large sample of private firms. An advantage of the Sageworks data, in comparison to the majority of researcher available US private firm datasets, is its longitudinal financial statement data, which enables investigation of the timeseries properties of private firm earnings and cash-flows and changes in financial performance and position. However, it is important to note that given the sampling and selection by both the data vendor and author, it is not a representative sample of US private firms. First, all sample firms must prepare financial statements. In general, private firms are not required to prepare non-tax related financial statements (Cassar 2009). Second, all sample firms are required to employ the services of an external accountant to prepare or verify their financial statements to some degree. Private firms may choose four levels of auditor association, namely an audit, a review, a compilation, or no association. This exclusion of no association firms is not trivial, as private firms are more likely to prepare their financial statements without external assistance or verification, than have them compiled, reviewed, or audited by accountants. Third, all the sample firms must use accrual accounting. Evidence suggests that most private firms employ a cash basis rather than accrual basis of accounting (Allee and Yohn 2009). Further, lenders frequently allow private firm applicants to submit financial information that deviates from GAAP, particularly in bases other than accrual accounting (AICPA, 2004; FERF, 2006). Fourth, there is truncation of sample firms for the empirical tests due to the observed extreme financial ratios, such as sales growth, which will eliminate smaller and riskier firms from the sample. ${ }^{1}$ All these criteria reduce sample heterogeneity which may better isolate the impact of

\footnotetext{
${ }^{1}$ Given Minnis [2010] uses a different sample and different selection criteria than Allee and Yohn [2009], it is unclear if having a reasonably similar average interest rate supports or rebuts the validity of the inferred cost of debt variable (see footnote 17 of Minnis [2010]).
} 
auditing. Moreover, given that the retention of external accountants and the voluntary preparation of financial statements that are in accordance with GAAP is strongly positively correlated with firm size (Allee and Yohn 2009; Cassar 2009; Cassar and Ittner 2009), all these criteria will skew the sample toward larger private firms. ${ }^{2}$ The focus on larger private firms, with less uncertainty and riskiness, reduces the importance of auditing in this sample relative to the broader population of private firms, suggesting the observed mean effects may actually understate the importance of auditing for private firms.

\subsection{ALTERNATIVE INFORMATION VERIFICATION CHANNELS}

Minnis [2010] asserts that the private firm setting overcomes an important complication when examining financial statement verification in a public firm setting, namely the avoidance of alternative information verification channels other than an audit. Unfortunately, this assertion is false. A more correct statement is that private firms have different sources of firm information and financial statement verification than public firms. While private firms do not have a market where potential investors value the firm and are not followed by sell-side analysts or the press, these firms have other hard and soft information sources not controlled for in this study that may substitute for auditor verification and audited financial statements.

There is a voluminous literature in finance on banking relationships and information asymmetries between firms and lenders, primarily focused on private firms (see e.g. Berger and Udell 1995; Berger and Udell 2002; Petersen and Rajan 2002; Bharath et al. in press). This evidence suggests that the "soft" information obtained through a lender's ongoing relationship with a borrower may be a better source of information about the borrower's credit worthiness than hard, quantitative information, such as financial statements (Petersen and Rajan, 1994; Cowen and Cowen, 2006). This

\footnotetext{
${ }^{2}$ Given the size of the sample firms it is likely the sample includes private firms with public debt who are subject to stronger reporting requirements. The presence of these firms, which are also larger and more likely to be audited, will induce a relation between auditing and lower cost of debt.
} 
information, such as a loan officer's knowledge of the potential borrower's ability, character, and trustworthiness, is "soft" in the sense that it is difficult to quantify and communicate to others, and may not be verifiable by outsiders (Berger and Udell, 1995; Petersen, 2004). Consequently, past and existing financing relationships, particularly those of longer duration, offer an important source of information that can reduce information asymmetries and the cost of debt for private firms (Diamond, 1991).

Financial statements are not the only source of "hard” information that lenders can use to evaluate the financial condition and performance of borrowers. All US private firms are required to submit tax returns to the Internal Revenue Service that are subject to compliance rules and penalties for misstatement. Given the compliance requirements, the conservative nature of tax-based accounting rules, and the incentives of firms to report tax income conservatively to minimize the present value of tax obligations many financiers request firms’ previously lodged tax returns. Credit scores also offer another method for obtaining hard, quantified information on private firms to assess the probability that borrowers will meet their loan obligations (Petersen, 2004). Credit scoring agencies, such as Dun \& Bradstreet and Fair Isaac, calculate these scores using a broad set of information on financial performance and condition, as well as credit history, business demographics, and other public information such as court judgments or liens (e.g., Frame et al., 2001; Akhavein et al., 2005; Berger et al., 2005). Broader availability of third-party credit scores and reduced cost of information transfer have led an increasing number of banks to utilize these scores in loan approval and pricing (Cowan and Cowan, 2006; Petersen, 2004). Consequently, the economics literature on small business lending suggests that third-party credit scores provide an alternative means for reducing information asymmetries by giving lenders a cost-effective and timely method of monitoring borrowers (Petersen and Rajan, 2002; Berger and Frame, 2007). Therefore, financial 
information in tax returns and credit scores provide alternative "hard” information that may substitute for furnished financial statements under GAAP.

The extent to which financial accounting verification and quality is a substitute or complement to these hard and soft alternative information sources is unclear, as the quality of these other sources varies across firms. While not observed by Minnis [2010] his findings do suggest that on average audited financial statements provide benefits beyond these other information sources. Exploiting the private firm setting to investigate the role of financial accounting quality and alternative information sources as a means for reducing information asymmetries is a fruitful area of research.

\subsection{OMITTED CORRELATED VARIABLES}

The private firm setting has several unique features that both exacerbate the importance of some influences and encourage the use of other mechanisms to reduce the impact of information asymmetries between the firm and lenders. Research on private firm financing, particularly using the SSBF, has documented many factors that substantially affect private firm loan pricing decisions, such as the loan characteristics, contractual terms, and the characteristics of the entrepreneur. As Minnis’s set of independent variables is confined to the firm's financial characteristics, it is likely that any of his findings derived from econometric methods that are susceptible to omitted correlated variable bias will be affected.

First, there is no information on the type of loans these firms have obtained. The extent that firm debt is comprised of line of credit versus various asset backed loans, such as mortgage, equipment, or motor vehicle loans is unclear. Other unobserved basic loan specific characteristics include the size of a given loan, loan maturity, and whether the loan has fixed or floating interest rate. All these loan characteristics have been shown to significantly affect the interest rates of private firm

loans (Cavalluzzo, Cavalluzzo, and Wolken 2002). Also, there is no information about the 
contracting terms of the loans, such as the use of collateral, guarantees, contingent provisions, covenants, or performance pricing. Financers can reduce the role or need for firm information and verification by including contracting provisions in the financing agreement, such as requiring collateral or personal guarantees. Research on debt financing shows the importance of these contractual features on loan terms for larger firms (Asquith Beatty and Weber 2005; Roberts and Sufi 2009), yet contracting term importance is heightened for smaller private firms (Berger and Udell 1998; Scholtens 1999). Further, empirical evidence shows that many of the contractual features in private firm loans, such as collateral use, are a function of firm characteristics, such as information opacity and riskiness (Berger and Udell 1990; Jimenez, Salas, and Saurina 2006). The unobserved loan type and contract features matter substantially for small firm lending, which by itself could explain the variations in firms' cost of debt.

Second, the nexus between the owner manager's ability and firm performance is substantially stronger in private firms. In many cases it is difficult to disentangle the human capital or financial capital of the owner-manager or entrepreneur from the firm (Wiklund and Shepherd 2003; Moskowitz and Vissing-Jorgensen 2002). Consequently, the characteristics of the owners and managers of private firms play a substantially more prominent role in the performance and loan pricing decisions than in public firms. Lenders can infer information about the owner's ability, which is associated with firm performance and likelihood of repayment of debt obligations, by the observed success of his current and previous businesses, the owner's formal education or industry-specific experience. Information about the owner's trustworthiness can be obtained from the personal credit history of the entrepreneur, such as whether he has previously defaulted, had judgments against him, or been in bankruptcy. All these dimensions have been shown to increase the cost of debt provided to owner-managed firms (Cavalluzzo, Cavalluzzo, and Wolken 2002). Further, the substantial literature that has investigated discrimination in small firm financing suggests that in some market settings US 
entrepreneurs do obtain different denial and interest rate terms on the basis of the gender and race of the entrepreneur (Bates 1991; Blanchflower, Levine, and Zimmerman 2003; Cavalluzzo, and Cavalluzzo 1998; Cavalluzzo, Cavalluzzo, and Wolken 2002). Therefore, not identifying and controlling for entrepreneur heterogeneity ignores significant variation that has been documented to affect private firm's cost of debt.

I use the 2003 Survey of Small Business Finances (SSBF) administrated by the Federal Reverse Board to demonstrate the potential unexplained variation in interest rates by comparing the explanatory power of excluded versus included variables. I discuss how interest rates are measured later, but even if interest rates were measured correctly, many important control variables are missing. The 2003 SSBF is a nationally representative sample of 4,240 for-profit, nonfinancial, nonfarm, nonsubsidiary business enterprises of fewer than 500 employees, constructed from a stratified random sample based on employment size, urban/rural status, and census divisions. The objective of my analysis is not to provide a complete model of independent variables to predict firm interest rates, as there are hundreds of candidate variables available in the SSBF, but to demonstrate that the inclusion of just a few omitted variables can explain a substantial amount of the variation observed in private firm loan pricing decisions. I focus my analysis on the 767 privately-held firms that used their firm's financial statements for the SSBF interview. ${ }^{3}$ These respondents were asked whether the financial statements were: 1$)$ audited $(n=226)$; 2$)$ reviewed $(n=168) ; 3)$ compiled $(n=$ 111), by a professional accountant or accounting firm; or 4) none of the above $(n=262)$. The dependent variable (Audit) is an indicator variable coded one if the firm is audited, and zero

\footnotetext{
${ }^{3}$ Given the wording of the question, the remaining 2,960 private firms with non-missing assets, sales, and shareholders may have prepared and furnished financial statements to debt financiers, but not used them specifically in the SSBF interview. These remaining respondents were not asked about auditor association. I also remove 52 firms that used their firm's financial statements for the SSBF interview but did not provide the firm's auditor association. Firms with imputed data are also excluded from the analysis.
} 
otherwise. Four hundred and thirty six of these firms applied for debt financing within the last three years, with 411 having some debt financing approved.

The variables I use to model firm interest rates are: the natural logarithm of the loan amount (Loan Amount), an indicator if the loan has a fixed (versus floating) interest rate (Fixed), an indicator if the loan is a line-of-credit loan (Line of Credit), an indicator if collateral is provided for the loan (Collateral), an indicator if an owner has declared bankruptcy or had a judgment rendered against them (Default), and an indicator if the race of the majority owner is non-white (Non-White). As observed from Table 1, these six variables with Audit explain 21.1 percent of the total variance in firm interest rates. Consequently, if these omitted variables are associated with audit choice, this will likely result in omitted correlated variable bias.

In the remaining models I include most of the variables from Minnis’s analysis, namely: the natural log of total firm assets (Firm Size), firm debt to assets (Leverage), an indicator if the firm has negative book equity (Negative Equity), an indicator if the firm had greater sales than three years earlier (Sales Growth), and an indicator if the firm was a C-Corporation (C-Corp). I also include return-on-assets $(R O A)$ to capture the effect of profitability on loan pricing, as interest coverage, in addition to current ratio and PPE, is not available in the SSBF. The explanatory power of these variables is 16.3 percent of the total variance in interest rates. However, as shown by the inclusion and exclusion of firm total assets, the majority of the explanatory power is driven by firm assets, with the explained variance decreasing to 5.6 percent when firm assets is removed from the model. Additionally, with the inclusion of firm total assets, none of the remaining variables in the model are significantly associated with interest rates, including Audit, which decreases substantially in economic magnitude with the inclusion of firm size. This highlights the strong association between firm size and audit that I will develop later. 
The right-most column of Table 1 provides the results of the interest rate model with all the independent variables listed above. If the omitted variables do not explain the variance in interest rates after the inclusion of Minnis’s variables then it is less likely these omitted variables will affect his study's results. However, these additional variables do continue to explain a substantial proportion of the variation in interest rates, with the model R-squared by including the six additional variables increasing from 16.3 to 24.9 percent. I find loans contracted with a fixed interest rate have an interest rate 145 basis points higher than loans with floating interest rates. Further, private firms that are majority owned by non-white owners have interest rates that are 130 basis points greater than firms that are majority owned by white entrepreneurs. The inclusion of additional control variables may mitigate the economic importance of these two variables; however, the fact that these variables have a substantial influence on interest rates after controlling for the majority of variables in Minnis’s model suggests that variables omitted from his study have an influential role in private firm interest rates. Given the economic magnitude of the omitted variable effects, even a weak association between these variables and firms' audit choice will induce a noticeable omitted correlated variable bias. While an omitted correlated variable bias cannot be ruled out or confirmed, the scope and explanatory power of variables not controlled for increases the likelihood that an omitted variable is spuriously affecting the results.

\subsection{APPROPRIATENESS OF INFERRED COST OF DEBT}

Minnis [2010] estimates firms’ cost of debt as the ratio of reported interest expense on the average of the beginning and ending total liabilities. This approach is used, rather than the ideal approach of identifying specific loans and their characteristics, as there is no loan specific information in his database. As acknowledged by the author, an estimated average cost of debt measure inferred from the income statement and balance sheet results in substantial noise in the dependent variable. However, these cost of debt measurement concerns are exacerbated when 
examining smaller private firms raising doubts as to the applicability of this measurement approach for the research setting.

First, the identification and measurement of liabilities, particularly debt that is contracted at arm's length, is less clear in smaller firms. Many private firms' balance sheets include liabilities representing loans from the owner-manager. The determination of an interest rate for a loan from the owner to his firm is to some degree arbitrary and often driven by tax considerations. Research also shows that a proportion of private firm financing is from insiders, such as friends and family, who have substantial knowledge of the firm or have strong ties to the entrepreneur, making them less likely to be subject to the entrepreneur's opportunistic behavior (Bates 1997; Cassar and Holmes 2003). Consequently, it is not clear that the interest rate of an insider-originated loan should be affected by whether the firm's financial statements are audited. More concerning is the extent to which insider-based private firm debt is not issued at arm's length, offered for altruistic reasons, or even issued without the intention of being repaid (Ang, 1992; Bygrave et al. 2003). It is debatable to what extent we can make economically reasoned inferences from interest expenses and debt that is not contracted on at arm's length. Further, there are problems with the identification of debt and equity or the use of quasi-equity by smaller firms, resulting in the arbitrary classification of some balance sheet financing (Ang, 1992; Cassar and Holmes 2003). Therefore, differences between private and public firms, such as the ability to accurately identify arm's length liabilities of firm outsiders, likely results in greater estimation noise when inferring cost of debt from private firms' financial statements.

Second, the inferred cost of debt measure suffers from staleness, in that a portion of the observed interest rate has been contracted on many years earlier. To demonstrate this point using other private firm data, the average (median) maturity for the 1,620 loans in the SSBF is 45 (16.5) 
months, with 30 percent of loans having a maturity 60 months or greater. ${ }^{4}$ Moreover, only 44.7 percent of the private firms in the SSBF applied for new loans or renewed existing loans in the previous three years, with 41.4 percent obtaining loans during this period. ${ }^{5}$ Further, even if the firm does take out a new loan, this loan amount is not the total amount of firm debt outstanding. Of the SSBF firms that obtained new loans, these loans represented approximately 36 percent of their total liabilities outstanding. This evidence demonstrates a substantial portion of the inferred contemporaneous interest rate of private firms relates to contracting that was undertaken many years earlier. These identification issues affect both the denominator (total liabilities) and numerator (interest expense), imparting considerable noise in the study's cost of debt dependent variable. Cost of debt staleness also reduces the effectiveness of the control variables given their potential variation over a several year period. Empirical approaches to address the reduced effectiveness of controls driven by the staleness in the inferred cost of debt measure include examining interest rate variation of firms that change auditor association status, as undertaken by Minnis (2010) on 31 firms and Kim, Simunic, Stein and Yi (2007) on 840 firms.

Third, all else equal, the audit process affects the values reported for interest expense and total liabilities. These measurement deviations will lead to differences in Minnis’s firms’ inferred interest rates even when firms have identical interest rates on their debt. Indeed, Minnis's thesis is that the audit process will change the accounting values reported in the financial statements, which may alter the financial ratios, such as cost of debt, in a systematic manner (Guenther, Maydew, and Nutter, 1997). For example, given the reporting incentives of firms and the role of the audit function, audited

\footnotetext{
${ }^{4}$ Using sample weights based on the population of US private firms the average (median) loan maturity is 53 (36) months.

${ }^{5}$ Fifty three point six percent of firms that provided auditor association in the SSBF obtained loans in the previous three years. This percentage is larger as this subsample includes larger private firms, which are more likely to obtain recent loans. Further, as Minnis's sample includes a greater proportion of larger private firms relative to the SSBF sample it is likely that a greater proportion of Minnis's sample have obtained recent loan financing compared to the SSBF sample.
} 
financial statements may be less likely to have omitted liabilities on the balance sheet. If so, firms with audited financial statements will have higher reported debt and leverage ratios, consistent with Minnis's univariate findings, and by construction a lower inferred cost of debt. Conversely, the audit function may ensure audited financial statements are less likely to have omitted or understated interest expenses on the income statement. Under these conjectures, the difference in cost of debt is not caused by a change in the firm’s explicit debt cost but by how auditing mechanically affects the measurement of the dependent variable in this study. How much of the variation in the cost of debt is driven by an actual lowering of interest rates on loans, as opposed to being driven by the measurement and reporting of the numerator and denominator is unclear.

Therefore, accurate identification of arm's length liabilities of firm outsiders, loan maturities beyond one year, and the effect of auditing on accounting values lead to significant noise and even systematic bias in the study's cost of debt dependent variable, especially when studying smaller firms.

\section{Endogenous Audit Choice}

\subsection{Is Auditing Always Voluntary?}

Generally, there is no mandated requirement for US private firms to have their financial statements audited. However, conference participants provided several examples where private firms are required to be audited. For example, a lender can require an audit for the firm to obtain a large working capital or asset based financing loan, which uses collateral from receivables. Having an audit is also a necessary requirement for firms to obtain some types of insurance. As noted by the author, an audit is often a condition to obtain a surety bond. If specific types of loans and outcomes are related to auditor association and also affect firm interest rates beyond auditing choice, this will induce a spurious correlation between audit use and firm interest rate. Both the type of financing and insurance used by the sample firms is unobservable from the data, and therefore, the extent to which 
this affects the findings is undetermined. However, it is important to note that the use of a valid instrument for audit use empirically overcomes a potential spurious association between auditing demand due to financing loan type or insurance on firm cost of debt.

\subsection{Validity of Instrument}

A concern with simply regressing firms' interest rates on firms' audit use to determine the effect of auditing on cost of debt is that the choice to be audited may be endogenously determined. If firms’ audit choices are correlated with unobserved factors that also affect firms' interest rates this will bias the coefficients from a simple regression model. Consequently, Minnis employs an endogenous switching model to account for potential selection bias and instruments the endogenous audit choice. To instrument for firms’ audit choice Minnis uses the percentage of firm-years that are audited in the vendor's database for each state. He argues that this instrument proxies for differences in states’ attestation regulatory environments, which influence the supply and demand for auditing services. The identification of an appropriate instrument in empirical research is a very difficult endeavor. A valid instrument for this study must be correlated with the independent variable of interest, firm audit choice, and unrelated to the dependent variable, firm cost of debt. Conference participants questioned the validity of Minnis’s instrument on several grounds.

First, it is unclear what the differences in state percentages of auditing use are capturing and whether they may have anything to do with the state's attestation regulatory environment. Beyond the licensure of Certified Public Accountants, this percentage may capture variations in taxation of business, corporate governance, wealth, education, and industry effects. Some of these factors are likely associated with firm interest rates. Even given all these potential differences it appears unlikely that the state's attestation regulatory environment can explain the observed variation in audit use across states. Conference participants questioned whether it is plausible that variations in state attestation regulation could explain differences in the likelihood of a private firm being audited across 
states from 8.1 percent to 38.5 percent. If the percentage of firms’ auditor use is simply capturing the state's banking or economic environment, is it likely that this instrument is not exogenous to firms’ interest rates. Minnis attempts to address this concern by orthogonalizing the state audit instrument to variables that proxy for the state's litigation and banking environment. However, the raw state audit instrument and the orthogonalized instrument have practically identical univariate correlations with the remaining study variables, so it is unclear how effective this treatment is. ${ }^{6}$ Given these plausibility concerns, conference participants suggested that a direct measure, based on state specific legislation and professional requirements, would be a more convincing choice of instrument.

Second, a likely explanation for the strong correlation $(\rho=0.22)$ between the likelihood that another private firm in the same state is audited and the firm's own audit choice is sample selection. As the instrument is not based on a population percentage of audit use but a vendor's database with non-random selection, this instrument is likely correlated with firm characteristics. Specifically, the data are primarily obtained from CPAs and banks who input their clients' financial data. As these service firms' client data are geographically clustered, any variation in the selection of firms by those inputting the data, or types of customers they serve, will induce correlation between the state audit and firm audit variables. For example, if a particular CPA only services large audit clients, this will artificially increase both the mean percentage of firms who are audited and mean firm size in a given state. As the variables state audit and size are highly correlated with audit choice, and explain essentially all the variation in the audit instrument, it is likely that the audit instrument is noisy proxy of omitted firm characteristics. Given these empirical concerns, particularly the mechanical endogeneity of audit choice in the instrument, it is unclear if the benefits of adopting an instrumented variable approach outweigh other econometric methods that do not rely on the identification of an exogenous instrument.

\footnotetext{
${ }^{6}$ Alternatively, the very similar correlations for the raw and orthogonalized versions of state audit proportion the
} 


\subsection{Propensity Score Matching}

Given the concerns of the instrument employed, Minnis [2010] performs additional analysis using propensity score matching. While a critique of propensity score matching is it cannot match on unobserved correlated variables, potentially resulting in an increase rather than a decrease in hidden bias, an advantage of propensity score matching is it does not require an assumption of linearity of the control variables on the treatment variable. ${ }^{7}$ Econometric methods that relax the linearity assumption may be particularly useful when research suggests a strong association between the control and treatment variable, such as firm size and firm audit use (Allee and Yohn 2009). The importance of not adequately controlling for firm size in this context should not be underestimated. As Minnis reports, simple matching by industry and firm size alone reduces the observed audit effect on firm cost of debt by one-third relative to the findings using an instrumental approach designed to control for firms’ endogenous audit choice.

Consistent with previous research, Minnis [2010] observes a univariate correlation between audit use and firm total assets of $\rho=0.30$. Further, he finds firm size is the primary explanatory variable in the model to explain firm audit choice $(t$-stat $=25.97)$. Beyond the instrument the remaining independent variables provide limited additional explanatory power on firms' audit choice. To demonstrate the role of firm size on SSBF firms, I model auditor use by the firm as a function of firm characteristics. I exclude variables related to loan characteristics, as these are very likely to be exogenous to the firm's auditor association choice. Table 2 provides the probit estimation for the model predicting auditor use. Similar to Minnis's sample, there is a strong positive association between auditor use and firm size for the SSBF sample $(z=4.75, p<0.001)$. Further, removing firm size from the probit model lowers the pseudo R-squared from 4.7 percent to 2.1 percent. This strong

${ }^{7}$ For a general discussion of alternative econometric approaches to address endogeneity, including instrumental variables and propensity matching, see Core [2010]. 
association, which has been observed in all previous auditing use research, highlights the importance of adequately controlling for firm size when estimating the effect of auditing on firm interest rates. Given these concerns Minnis employs propensity score matching incorporating firm size controls and in robustness tests truncates the sample to reduce size-related heterogeneity. Importantly, Minnis reports that his inferences are unchanged when using a propensity score matching approach. However, Minnis finds the average treatment effect of auditing on firm interest rates is highly sensitive to small changes in the potential impact of unobservable variables. As discussed earlier, there are many potential omitted variables that are strongly associated with firm interest rates, which may result in spurious observed effects between auditing and firm interest rates. Therefore, I agree with the author's assessment that the inferences from these propensity score tests should be viewed with some skepticism.

To investigate the potential the non-effect of audit use on interest rates in the SSBF sample is driven by inadequate control for firm size and other firm characteristics, I perform a propensity matching estimation described by Minnis [2010] using the SSBF variables provided in the probit model above. I observe an average treatment effect of -0.299 for audited firms, which is larger than the estimate obtained using OLS that does not control for audit choice endogeneity. However, this treatment effect is not statistically significant $(\mathrm{se}=0.343, \mathrm{t}=-0.871$, iterations $=1,000$ ) and highly sensitive to the inclusion of additional control variables. For example, inclusion of the variables related to loan characteristics with the determinant variables of auditor use in Table 2 results in an average treatment effect of -0.060 for audited firms (se $=0.373, t=-0.162$, iterations $=1,000$ ). Therefore, like Minnis's propensity score findings, the propensity score estimates from the SSBF sample should be viewed with caution.

Finally, one important feature between the various econometric methods that is ignored is the extent that the determinant variables of auditor use are stable. This is important as the audit 
verification choice of a firm is very sticky. An explanation for the stickiness is the strong negative signal of firm position and performance and subsequent reputation costs borne by the firm if it removes audit verification. In fact, of the 26,005 firm-years with consecutive years of firm data, the author mentioned there were only 31 occasions where audit association changed. ${ }^{8}$ Therefore, the choice to use an auditor for the majority of sample firms was made many years before observing the firm. Consequently, many of the financial characteristics of the firm, such as interest coverage and current ratio, may be very different than those modeled in the year investigated. Given that firm size and state affiliation are the two most important determinants of the endogenous audit choice and that these variables are relatively stable over time compared to accounting variables, simple matching or propensity matching across these two dimensions to control for the sticky auditing choice intuitively seems more convincing than the instrumented variable approach in the paper.

\section{Hypotheses}

\subsection{DOES AUDITING RESULT IN GREATER SENSITIVITY TO FINANCIAL INFORMATION? (HYPOTHESIS TWO)}

The paper's second hypothesis is that the cost of debt is more sensitive to the financial information of audited firms. Specifically, the audit verification of the firm's accounting process and reporting gives the firm's financial statements greater credibility, resulting in lenders' pricing decisions being more sensitive to variations in accounting ratios of audited firms. To empirically test variations in loan pricing sensitivity Minnis compares the coefficients of accounting ratios from an endogenous switching model predicting cost of debt for audited and non-audited firms. He finds three of the seven accounting ratios, interest coverage, current ratio, and PPE, have significantly larger

\footnotetext{
${ }^{8}$ Note the changes in firm audit association are substantially understated due to the requirement that firms be in the dataset for consecutive years. As CPAs are the most prominent inputters of data, firms that hire accountants for the first time will generally not be included in this sample.
} 
negative coefficients for audited firms and concludes from this evidence that cost of debt is more sensitive to audited financial information. However, there are several concerns with this inference.

First, it is unclear why these three particular ratios of the seven accounting variables investigated are of most importance to loan pricing decisions, aside from these three having statistically significant differences in the direction hypothesized. For example, it is uncertain why lenders loan pricing decisions should be more sensitive to variations in a firm's current ratio due to auditing but not be more sensitive to variations in a firm’s leverage and negative equity. Further, two of the remaining four changes in accounting variable coefficients are in the opposite direction one would predict if firm auditing resulted in greater sensitivity to accounting variables. ${ }^{9}$ Taken as a whole and without further elaboration from the author, the change in coefficients between audited and non-audited firms is not very convincing evidence to support the second hypothesis.

Second, there are concerns with the validity of the estimated coefficients. For example, the coefficient on negative equity for audited firms is significantly different in the opposite direction hypothesized, with audited (non-audited) firms with negative equity having a reduction in their cost of debt of 85 (1) basis points. A theoretical explanation as to why only audited firms with negative equity would be rewarded with significantly lower interest rates is not obvious. As another example, it is unclear why non-audited firms have a lower cost of debt as their leverage, and therefore riskiness, increases. The endogenous switching model allows the effect of firm characteristics on interest rates to vary between audited and non-audited firms to maximize the model's overall explanatory power. ${ }^{10}$ However, interpretation of an average treatment effect becomes more tenuous

\footnotetext{
${ }^{9}$ Another variable, while statistically different, is ambiguous as to whether the change in coefficients supports or contradicts the notion that auditing will result in loan pricing exhibiting greater sensitivity to accounting information.

${ }^{10}$ A few prior studies have found a similar relation between leverage and cost of debt, but none of these studies use econometric techniques that allow the effect of leverage on cost of debt to vary within sample.
} 
when the estimated effect of the remaining variables on the dependent variable differs substantially across treatment groups for non-obvious or counter-intuitive reasons.

Third, and more generally, it is not clear if auditing should result in significantly more negative coefficients on financial statement variables. Consider PPE, which had the strongest observed difference between audited and non-audited firms. If a lender has higher quality or complete information about the firm's financial performance the verification of the firm's tangible assets becomes less important, which is the opposite direction predicted by Minnis. In general, the importance of tangible assets on loan pricing and the interest rate benefit from providing collateral will be greater for more risky or informationally opaque firms (Ortiz-Molina and Penas 2008). Therefore, it is unclear if the weight on financial statement information, particularly balance sheet information, should increase uniformly as higher quality firm information is obtained by lenders. Both the estimation results and the ex ante ambiguity about why all financial statement information would be more important for audited firms raises doubt that the evidence is generally consistent with cost of debt being more sensitive to financial statement information of audited firms.

\subsection{DO AUDITORS INCREASE THE PERSISTENCE OF NET INCOME? (HYPOTHESIS THREE)}

The paper's third hypothesis is that audit verification improves the predictive ability of reported net income on future cash flows. Minnis [2010] uses the empirical approach of Barth, Cram and Nelson [2001] to estimate the predictive ability (persistence) of current cash flows and accruals on future cash flows. Consistent with his arguments he finds (in Table 8) greater persistence in net income for audited firms than non-audited firms, both in the cash flow and accrual component of net income. Specifically, the cash flow coefficient for audited (non-audited) firms on one-year ahead cash flow is 0.625 (0.560) and the coefficient on net income for audited (non-audited) firms is 0.638

(0.503). Comparing these coefficients to Barth, Cram and Nelson's [2001] findings suggests that the 
ability of accruals to predict future cash flows in audited private firms is approximately three times greater for than for publicly listed firms (ACCRUALS = 0.22; BCN 2001 Table 4, column 1). Obviously, readers should not conclude from this joint comparison that smaller private firms have greater persistence of accruals than larger public firms as it contradicts previous empirical evidence and Minnis’s size-related hypothesis.

An alternative explanation for these unusual findings is the different estimation process used by Minnis, compared to Barth, Cram and Nelson [2001], to determine cash flows and accruals which induces significant noise in the accrual and cash flow variables. Specifically, Minnis [2010] obtains earnings from the income statement and estimates accruals using Sloan's [1996] balance sheet approach, summing the changes in end-of-year balances of various assets and liabilities. He then estimates net cash flow from operations as earnings minus accruals. The estimation of accruals and cash flows using the balance sheet approach is heavily dependent on the measurement accuracy of the balance sheet components, which is lower in private firms. The balance sheet method is also sensitive to the many influences, such as articulation between years, and extraordinary items, which are identified in public firm databases but usually not in private firm databases (Hribar and Collins 2002). Outside of this explanation or sample truncation, the magnitude of difference observed in the accrual coefficients across these two studies (in the opposite direction to that suggested by prior research) raises doubt as to the validity of the paper’s persistence findings.

Moreover, conference participants suggested splitting total accruals into its various components to isolate which specific accruals improve their informativeness from being audited. For example, should it be that accruals related to revenue recognition will have the same auditor benefit and those related to inventory? Some accrual measurement may benefit more from auditing due to extent of managerial discretion, ease of manipulation, expertise to measure, or greater uncertainty 
(Richardson et al. 2005). Examination of potential heterogeneity in persistence across accrual components could result in better identification of the benefits from auditor use.

The broader question is whether the improved predictive ability of net income on one-yearahead cash flow is a primary mechanism for why audited firms have a lower cost of debt. There are several other potential reasons why auditing affects firms’ cost of debt. For example, an audit reduces the need for a financier to expend resources in verifying the faithfulness of the firm's financial position and performance in the financial statements. Given competition in firms' debt financing, this reduction in monitoring costs should be reflected in a lower cost of debt offered to the firm. Further, as audits provide assurance through comprehensively evaluating the firm's accounting operations and controls, auditors can provide benefits to lenders beyond financial reporting. For example, validating the effectiveness of how cash is transferred and monitored throughout the firm reduces the likelihood of fraud by management.

Even within the sphere of financial reporting are debt financiers more interested in the persistence of earnings components and the mapping of future events in current financial statements or specifically the timely revelation of bad outcomes? (Guay and Verrecchia 2006). As mentioned in a footnote, Minnis [2010] also finds that audited firms do report more conservatively. However, persistence and conservatism are not analogous and capture very different constructs. For example, the empirical correlation between timely loss recognition and persistence is lower than two percent (Dechow Ge Schrand, 2010). Further, if auditor use increases the likelihood that a firm writes down their book asset values this will increase the firm's timely loss recognition; however, it may decrease earnings persistence. Understanding the mechanisms by which firms benefit from auditing is an ongoing and interesting area of research.

\subsection{WHAT DOES FIRM SIZE CAPTURE?}


Minnis [2010] argues that both the interest rate reductions and the improvement in predictive ability of accruals from auditing are stronger in smaller firms because smaller firms have weaker accounting systems. The assertion that internal accounting capabilities and accounting system quality is increasing in firm size is entirely consistent with empirical evidence (Allee and Yohn 2009; Cassar 2009). However, firm size is also correlated with many other firm attributes, including uncertainty, complexity, available resources, riskiness, and information asymmetry (Berger and Udell 1998; Bharath et al. in press). Therefore, without better identification it is uncertain what the size-related partitions capture.

Consider an alternative argument for the size-related findings that auditors provide greater assistance to firms where there is greater uncertainty. Many studies have documented that smaller firms have greater variability in performance and greater uncertainty (Cassar and Gibson 2008). In regard to persistence, researchers argue that larger firms have more stable and predictable operations which results in more accurate accrual estimation (Dechow and Dichev 2002). Indeed, the results from Minnis [2010] (Table 10) show that larger firms have greater persistence in both accruals and cash flows. Unfortunately, there is little attempt to disentangle alternative explanations for why auditors matter more. Therefore, whether the size results are driven by firm internal capabilities versus other size correlated constructs is unclear.

Further, for the sized-based auditing results to be driven by smaller firms having weaker accounting systems requires an assumption that firms with different accounting internal capabilities will not systematically differ in their demand for non-audit external accounting assistance. Firms that do not undertake audits for their financial statements can still employ professional accountants for review, compilation, tax return preparation, management advisory and other services. The provision of non-audit services by external accountants may increase the sophistication of firm's internal accounting systems or create economic bonds that weaken auditor independence and diminish audit 
quality, reducing the benefit of formal auditing services (Lim and Tan 2008). Alternatively, non-audit services may allow auditors to use their firm specific knowledge to further improve the firm's accounting systems and audit quality. Interestingly, research suggests that accounting expertise in private firms, as represented by owner-managers' occupational accounting experience, actually increases the likelihood that the firm retains an external accountant (Cassar and Ittner 2009). The role of non-audit accountant association is not considered and assumed constant across firms in Minnis's study. Therefore, the extent that non-audit services effect firm internal accounting sophistication and influence the benefit of auditing services on firms’ cost of debt is uncertain.

\section{Conclusion}

In this discussion I review Minnis [2010] in the context of the broader literature on private firm financing. I describe the unique features private firm setting and how it affects research design and inference. I detail the alternative information sources available to debt financiers of private firms that may limit the role of auditors and firm financial statements. Further, I review the broad literature in the private firm setting that documents the many omitted correlated variables that affect cost of debt. Differences between private and public firms, such as the ability to accurately identify arm's length liabilities of firm outsiders, likely results in greater estimation noise when inferring cost of debt from firms’ financial statements.

There are several concerns regarding the validity of the econometric methods used and the specific hypotheses raised by Minnis [2010]. Given the empirical concerns about the instrument used, particularly its potential mechanical endogeneity, matching-based approaches that do not rely on the identification of an exogenous variable arguably provide more convincing evidence. There was further potential to explore the specific mechanisms by which auditors affect cost of debt and disentangle why the auditors appear to assist small firms more than large firms. But these debates aside, Minnis [2010] investigates an important and timely topic. The private firm setting offers many 
opportunities to understand fundamental accounting issues. Researchers that exploit the varied environmental, regulatory and other forces that affect private firms and the empirical variation in this setting can provide many important insights. 


\section{REFERENCES}

AKHAVEIN, J.; W. S. FRAME; and L. WHITE. "The diffusion of financial innovation: An examination of the adoption of small business credit scoring by large banking organizations." Journal of Business 78 (2005): 577-596.

ALLEE, K. D., and T. L. YOHN. "The demand for financial statements in an unregulated environment: An examination of the production and use of financial statements by privately-held small businesses.” The Accounting Review 84 (2009): 1-25.

AMERICAN INSTITUTE OF CERTIFIED PUBLIC ACCOUNTANTS (AICPA) AND FINANCIAL ACCOUNTING STANDARDS BOARD (FASB). Enhancing the Financial Accounting and Reporting Standard-Setting Process for Private Companies. Norwalk, CT: FASB. (2006).

ANG, J. S. “On the theory of finance for privately held firms.” Journal of Small Business Finance 1 (1992), 185-203.

ASQUITH, P.; A. BEATTY; and J. WEBER. "Performance pricing in bank debt contracts.” Journal of Accounting and Economics 40 (2005): 101-128.

BARTH, M. E.; D. P. CRAM; and K. K. NELSON. "Accruals and the prediction of future cash flows.” The Accounting Review 76 (2001): 27-58.

BATES, T. "Commercial bank financing of white- and black- owned small business start-ups." Quarterly Review of Economics and Business 31(1991): 64-80.

BATES, T. A. "Financing small business creation: The case of Chinese and Korean immigrant entrepreneurs.” Journal of Business Venturing 12 (1997): 109-124.

BERGER, A. N., and G. F. UDELL. “Collateral, loan quality and bank risk.” Journal of Monetary Economics 25 (1990): 21-42.

BERGER, A. N., and G. F. UDELL. "Line of credit and relationship lending in small firm finance." Journal of Business 68 (1995): 351-381.

BERGER, A. N., and G. F. UDELL. "The economics of small business finance: The roles of private equity and debt markets in the financial growth cycle.” Journal of Banking and Finance 22 (1998): 613-673.

BERGER, A. N., and G. F. UDELL. "Small business credit availability and relationship lending: the importance of bank organizational structure.” The Economic Journal 112 (2002): F32-F53.

BERGER, A. N., and W. S. FRAME. “Small business credit scoring and credit availability.” Journal of Small Business Management 45 (2007): 5-22.

BERGER, A. N.; W. S. FRAME; and N. MILLER. “Credit scoring and the availability, price and risk of small business credit.” Journal of Money, Credit, and Banking 37 (2005): 191-222. 
BHARATH, S. T.; S. DAHIYA; A. SAUNDERS; and A. SRINIVASAN. "Lending relationships and loan contract terms.” Review of Financial Studies. in press. doi: 10.1093/rfs/hhp064

BLACKWELL, D. W.; T. R. NOLAND; and D. B. WINTERS. "The value of auditor assurance: Evidence from loan pricing.” Journal of Accounting Research 36 (1998): 57-70.

BLANCHFLOWER, D. G.; LEVINE, P. B.; and ZIMMERMAN, D. J. "Discrimination in the smallbusiness credit market.” The Review of Economics and Statistics 85 (2003): 930-943.

BYGRAVE, W. D.; M. HAY; E. NG; and P. REYNOLDS. "Executive forum: a study of informal investing in 29 nations composing the Global Entrepreneurship Monitor.” Venture Capital 5 (2003): 101-116.

CANO-RODRIGUEZ, M. "Big auditors, private firms and accounting conservatism: Spanish evidence.” European Accounting Review 19(2010): 131-159.

CASSAR, G. "Financial statement and projection preparation in start-up ventures." The Accounting Review 84 (2009): 27-51.

CASSAR, G., and GIBSON, B. "Budgets, internal reports and manager forecast accuracy." Contemporary Accounting Research 25 (2008): 707-737.

CASSAR, G., and HOLMES, S. "Capital structure and financing of SMEs: Australian evidence." Accounting and Finance 43 (2003): 123-147.

CASSAR, G., and ITTNER, C. D. "Initial retention of external accountants in start-up ventures." European Accounting Review 18 (2009): 313-340.

CAVALLUZZO, K. S., and L. C. CAVALLUZZO. "Market structure and discrimination: The case of small businesses.” Journal of Money, Credit and Banking 30 (1998): 771-792.

CAVALLUZZO, K. S.; L. C. CAVALLUZZO; and J. D. WOLKEN. "Competition, small business financing, and discrimination: Evidence from a new survey.” Journal of Business 75 (2002): 641679.

CORE, J. "Discussion of chief executive officer incentives and accounting irregularities." Journal of Accounting Research 48 (2010), 273-287.

COWEN, C. D., and A. M. COWEN. A Survey Based Assessment of Financial Institution Use of Credit Scoring for Small Business Lending. Office of Advocacy, The United States Small Business Administration, 2006.

DECHOW P. M., and I. D. DICHEV. "The quality of accruals and earnings: The role of accrual estimation errors.” The Accounting Review 77 (2002): 35-59. 
DECHOW, P.; W. GE; and C. SCHRAND. "Understanding earnings quality: A review of the proxies, their determinants and their consequences.” Unpublished paper, University of Pennsylvania. 2010.

FINANCIAL EXECUTIVES RESEARCH FOUNDATION (FERF). What do users of private company financial statements want? Florham Park, NJ: FERF, 2006.

FRAME, W. S; A. SRINIVASAN; and L. WOOSLEY. "The effect of credit scoring on smallbusiness lending.” Journal of Money, Credit and Banking 33 (2001): 813-825.

GUAY, W., and R. VERRECCHIA. "Discussion of an economic framework for conservative accounting and Bushman and Piotroski (2006).” Journal of Accounting and Economics 42 (2006): 149-165.

GUENTHER, D. A.; E. L. MAYDEW; and S. E. NUTTER. "Financial reporting, tax costs, and book-tax conformity.” Journal of Accounting and Economics 23 (1997): 225-248.

HOUGHTON, K. A. "Audit reports: Their impact on the loan decision process and outcome: An experiment.” Accounting and Business Research 53 (1983): 15-20.

HRIBAR, P., and D. W. COLLINS. "Errors in estimating accruals: Implications for empirical research.” Journal of Accounting Research 40 (2002): 105-134.

INTERNATIONAL ACCOUNTING STANDARDS BOARD (IASB). International Financial Reporting Standard for Small and Medium-sized Entities. London, UK: IASB, 2007.

JIMENEZ, G.; V. SALAS; and J. SAURINA. “Determinants of collateral.” Journal of Financial Economics 81 (2006): 255-281.

JOHNSON, D. A.; K. PANY; and R. WHITE. “Audit reports and the loan decision: Actions and perceptions.” Auditing: A Journal of Practice and Theory 2 (1983): 38-51.

KIM, J-B, D. SIMUNIC; M., STEIN, and C. YI. "Voluntary audits and the cost of debt capital for privately-held firms: Korean evidence.” Working paper. 2007. (forthcoming Contemporary Accounting Research).

LIM, C-Y., and H-T. TAN. "Non-audit service fees and audit quality: The impact of auditor specialization.” Journal of Accounting Research 46 (2008): 199-246.

MCKINLEY, S.; K. PANY; and P. M. J. RECKERS. "An examination of the influence of CPA firm type, size, and MAS provision on loan officer decisions and perceptions.” Journal of Accounting Research 23 (1985): 887-896.

MINNIS, M. "The value of financial statement verification in debt financing: Evidence from private firms.” Unpublished paper, University of Chicago. 2010.

MOSKOWITZ, T. J. and A. VISSING-JORGENSEN. “The returns to entrepreneurial investment: a private equity premium puzzle.” American Economic Review 92 (2002): 745-778. 
NAIR, R. D., and L. E. RITTENBERG. "Alternative accounting principles for smaller businesses: Proposals and analysis.” Journal of Commercial Bank Lending (1983. April): 2-21.

NAIR, R. D., and L. E. RITTENBERG. "Messages perceived from audit, review, and compilation reports: Extension to more diverse groups.” Auditing: A Journal of Practice and Theory 7 (1987): 15-38.

ORTIZ-MOLINA, H., and M. F. PENAS. "Lending to small businesses: The role of loan maturity in addressing information problems.” Small Business Economics 30 (2008): 361-383.

PANY, K., and C. H. SMITH. "Auditor association with quarterly financial information: An empirical test.” Journal of Accounting Research 20 (1982): 472-481.

PETERSEN, M. A., and R. G. RAJAN. "The benefits of lending relationships: Evidence from small business data.” Journal of Finance 49 (1994): 3-37.

PETERSEN, M. A., and R. G. RAJAN. "Does distance still matter? The information revolution in small business lending.” Journal of Finance 57 (2002): 2533-2570.

PETERSEN, M.A. “Information: Hard and soft.” Unpublished paper, Northwestern University, 2004.

PILLSBURY, C. M. “Limited assurance engagements.” Auditing: A Journal of Practice and Theory 4 (1985): 63-79.

RECKERS, P. M. J., and K. PANY. “Quarterly statement reliability and auditor association.” Journal of Accountancy (1979. October): 97-100.

RICHARDSON, S. A.; R. G. SLOAN; M. T. SOLIMAN; and I. TUNA. "Accrual reliability, earnings persistence and stock prices.” Journal of Accounting and Economics 39 (2005): 437485.

ROBERTS, M. R., and A. SUFI. "Renegotiation of financial contracts: Evidence from private credit agreements.” Journal of Financial Economics 93 (2009): 159-184.

SCHOLTENS, B. “Analytical issues in external financing alternatives for SBEs.” Small Business Economics 12 (1999): 137-148.

SLOAN, R. G. "Do stock prices fully reflect information in accruals and cash flows about future earnings?” The Accounting Review 71 (1996): 289-315.

STRAWSER, J. R. "The role of accountant reports in users' decision-making processes: A review of empirical research.” Journal of Accounting Literature 10 (1991): 181-208.

WIKLUND, J., and D. SHEPHERD. “Aspiring for, and achieving growth: The moderating role of resources and opportunities.” Journal of Management Studies 40 (2003): 1919-1941. 
TABLE 1

Interest Rate Analysis

\begin{tabular}{|c|c|c|c|c|c|c|c|c|}
\hline \multirow[b]{3}{*}{ Independent variables } & \multicolumn{2}{|c|}{ (1) } & \multicolumn{2}{|c|}{$(2)$} & \multicolumn{2}{|c|}{ (3) } & \multicolumn{2}{|c|}{ (4) } \\
\hline & \multicolumn{2}{|c|}{ Omitted Variables } & \multicolumn{2}{|c|}{ Without Firm Size } & \multicolumn{2}{|c|}{ With Firm Size } & \multicolumn{2}{|c|}{ All Variables } \\
\hline & Coefficient & Std. error & Coefficient & Std. error & Coefficient & Std. error & Coefficient & Std. error \\
\hline Audit & -0.170 & 0.291 & -0.479 & 0.310 & -0.023 & 0.300 & -0.107 & 0.291 \\
\hline Loan Amount & $-0.889 * * *$ & 0.196 & & & & & -0.278 & 0.271 \\
\hline Fixed & $1.372 * * *$ & 0.341 & & & & & $1.454^{* * *}$ & 0.339 \\
\hline Line of Credit & 0.225 & 0.334 & & & & & 0.113 & 0.332 \\
\hline Collateral & 0.049 & 0.309 & & & & & 0.076 & 0.306 \\
\hline Default & -0.253 & 0.824 & & & & & -0.266 & 0.822 \\
\hline Non-White & $1.446 * * *$ & 0.446 & & & & & $1.303^{* * *}$ & 0.443 \\
\hline Firm Size & & & & & $-1.267 * * *$ & 0.186 & $-0.716^{* * *}$ & 0.269 \\
\hline ROA & & & $0.368 * *$ & 0.148 & 0.053 & 0.147 & 0.139 & 0.144 \\
\hline Leverage & & & -0.398 & 0.340 & -0.565 & 0.322 & -0.358 & 0.315 \\
\hline Negative Equity & & & 0.779 & 0.578 & 0.422 & 0.548 & 0.269 & 0.526 \\
\hline Sales Growth & & & $-0.721^{* *}$ & 0.297 & -0.425 & 0.284 & -0.417 & 0.271 \\
\hline C-Corp & & & -0.395 & 0.303 & -0.112 & 0.289 & -0.269 & 0.279 \\
\hline Intercept & & & $6.226 * * *$ & 0.349 & $13.941 * * *$ & 1.179 & $11.162 * * *$ & 1.316 \\
\hline $\mathrm{R}^{2}$ & \multicolumn{2}{|c|}{0.211} & \multicolumn{2}{|c|}{0.056} & \multicolumn{2}{|c|}{0.163} & \multicolumn{2}{|c|}{0.249} \\
\hline F-stat & \multicolumn{2}{|c|}{$14.000 * * *$} & \multicolumn{2}{|c|}{$3.652 * * *$} & \multicolumn{2}{|c|}{$10.158^{* * *}$} & \multicolumn{2}{|c|}{$9.174 * * *$} \\
\hline $\mathrm{n}$ & \multicolumn{2}{|c|}{374} & \multicolumn{2}{|c|}{374} & \multicolumn{2}{|c|}{374} & \multicolumn{2}{|c|}{374} \\
\hline \multicolumn{9}{|c|}{$\begin{array}{l}\text { a Table reports ordinary least squares estimation. Dependent variable is the interest rate on the entity's most recent loan. Independent variables } \\
\text { are: an indicator variable if the firm is audited (Audit), the log } 10 \text { of the loan amount (Loan Amount), an indicator if the loan has a fixed interest } \\
\text { rate (Fixed), an indicator if the loan is a line-of-credit loan (Line of Credit), an indicator if collateral is provided for the loan (Collateral), an } \\
\text { indicator if an owner has declared bankruptcy or had a judgment rendered against them (Default), an indicator if the race of the majority owner } \\
\text { is non-white (Non-White), the log } 10 \text { of total firm assets (Firm Size), firm return-on-assets (ROA), firm debt to assets (Leverage), an indicator it } \\
\text { the firm has negative book equity (Negative Equity), an indicator if the firm had greater sales than three years earlier (Sales Growth), and an } \\
\text { indicator if the firm was a C-Corporation (C-Corp). All indicator variables are coded one if true, and zero otherwise. Financial ratios } \\
\text { (Leverage, } R O A \text { ) are Winzorized at } 5 \text { percent based on the } 767 \text { firms that provided auditor association in the SSBF. ***, **, } * \text { denotes } \\
\text { significance at } 1,5 \text { and } 10 \text { percent level (two-tailed), respectively. }\end{array}$} \\
\hline
\end{tabular}


TABLE 2

Prediction Model for Use of Auditor

\begin{tabular}{|c|c|c|c|c|}
\hline \multirow[b]{3}{*}{ Independent variables } & \multicolumn{2}{|c|}{ (1) } & \multicolumn{2}{|c|}{ (2) } \\
\hline & \multicolumn{2}{|c|}{ With Firm Size } & \multicolumn{2}{|c|}{ Without Firm Size } \\
\hline & Coefficient & Std. error & Coefficient & Std. error \\
\hline Firm Size & $0.284^{* * *}$ & 0.060 & & \\
\hline ROA & $-0.107 * *$ & 0.054 & $-0.174 * * *$ & 0.052 \\
\hline Leverage & $0.179 *$ & 0.105 & 0.150 & 0.104 \\
\hline Negative Equity & -0.271 & 0.213 & $-0.361^{*}$ & 0.211 \\
\hline Sales Growth & $-0.173^{*}$ & 0.103 & -0.085 & 0.100 \\
\hline C-Corp & -0.179 & 0.129 & 0.039 & 0.119 \\
\hline Default & -0.067 & 0.355 & -0.142 & 0.352 \\
\hline Non-White & 0.070 & 0.153 & 0.031 & 0.152 \\
\hline Intercept & $-2.002 * * *$ & 0.347 & -0.485 & 0.130 \\
\hline Pseudo $\mathrm{R}^{2}$ & \multicolumn{2}{|c|}{0.047} & \multicolumn{2}{|c|}{0.021} \\
\hline$\chi^{2}$ & \multicolumn{2}{|c|}{$42.12 * * *$} & \multicolumn{2}{|c|}{$18.91 * * *$} \\
\hline Log likelihood & \multicolumn{2}{|c|}{-428.046} & \multicolumn{2}{|c|}{-439.653} \\
\hline $\mathrm{n}$ & \multicolumn{2}{|c|}{744} & \multicolumn{2}{|c|}{744} \\
\hline \multicolumn{5}{|c|}{$\begin{array}{l}{ }^{\mathrm{a}} \text { Table reports probit estimation. Dependent variable (Audit) is coded one if the firm is audited and zerc } \\
\text { otherwise. Independent variables are the log } 10 \text { of total firm assets (Firm Size), firm return-on-assets } \\
\text { (ROA), firm debt to assets (Leverage), an indicator if the firm has negative book equity (Negative } \\
\text { Equity), an indicator if the firm had greater sales than three years earlier (Sales Growth), an indicator if } \\
\text { the firm was a C-Corporation (C-Corp), an indicator if an owner has declared bankruptcy or had a } \\
\text { judgment rendered against them (Default), and an indicator if the race of the majority owner is non- } \\
\text { white (Non-White). All indicator variables are coded one if true, and zero otherwise. Financial ratios } \\
\text { (Leverage, ROA) are Winzorized at } 5 \text { percent based on the } 767 \text { firms that provided auditor association } \\
\text { in the SSBF. }{ }^{* * *}, * *, * \text { denotes significance at } 1,5 \text { and } 10 \text { percent level (two-tailed), respectively. }\end{array}$} \\
\hline
\end{tabular}

